\title{
COLLECTIVE MANIFESTATION OF EUROSCEPTIC PARTIES AND GROUPS CRITICAL IDEAS IN EUROPEAN UNION TREATIES
}

\author{
Palupi Anggraheni, S.IP, M.A, Chitra Regina Apris, S.Sos \\ Department of International Relations \\ Universitas Pembangunan Nasional Veteran Jawa Timur \\ Universitas Muhammadiyah Malang \\ E-mail : palupi.anggraheni.hubint@upnjatim.ac.id \\ reginaapris@gmail.com
}

\begin{abstract}
ABSTRAK
Mundurnya Britania Raya dari keanggotaan Uni Eropa (UE) meningkatkan kesadaran atas kemunculan ideide Eurosceoticism. Sebagai salah satu negara dengan peran penting di UE, keputusan ini tentu membawa konsekuensi khususnya pada sejauh mana ide-ide Eurosceoticism dimaknai oleh negara-negara anggota EU lainnya. Penelitian ini berfokus pada bagaimana ide kritis partai Eurosceptic termanifestasi dalam perjanjian-perjanjian Uni Eropa. Jenis penelitian ini adalah deskriptif kualitatif. Penelitian ini berfokus pada partai dan gerakan Euroscepticism di Austria, Belanda, Prancis, Italia, dan Inggris. Dalam studi ini, penulis menggunakan konsep Euroscepticism untuk menjelaskan klasifikasi partai kedalam kategori Euroscepticism Hard dan Soft dan skema Value-Added Collective Behaviour Neil J. Smelser untuk menjabarkan determinan tindakan kolektif mereka dalam menentang Uni Eropa. Hasil dari penelitian ini adalah Euroscepticism menyebar ke seluruh Eropa dengan memanifestasikan ide kritik mereka melalui enam faktor penentu diantaranya adalah Kondusifitas Struktural, Ketegangan Struktural, Pertumbuhan dan persebaran kepercayaan umum, Faktor pemicu, Mobilisasi partisipan, dan Kontrol sosial. Manifestasi ide kritis yang dilakukan partai-partai Euroscepticism di ketiga negara tersebut telah terlihat dari Single European Act, Maastricht Treaty, Treaty Establishing Constitution for Europe, Referendum British Exit. Puncak dari tindakan kolektif oleh partai-partai Eurosceptic adalah peluncuran kampanye-kampanye kritik Uni Eropa (No to EU!) serta perolehan suara yang signifikan pada pemilihan parlemen Uni Eropa.
\end{abstract}

Kata Kunci: Collective Behaviour, Criticism, Euroscepticism, Value-Added Scheme

\section{ABSTRACT}

The withdrawal of the United Kingdom from the European Union (EU) increases awareness of how far the Euroscepticism ideas spread among EU's members. As one of the pivotal EU members, the UK's withdrawal will bring consequences, especially how other countries' members perceived this action. The research focuses on how far the Eurosceptic party's critical ideas are manifested in the European Union treaties. This type of research is descriptive and qualitative. The scope of this research will focus on the Euroscepticism parties and movements in Austria, France, Italy, Netherland, and the United Kingdom. In this study, the authors use the concept of Euroscepticism to explain the classification of parties into the Euroscepticism Hard and Soft category and Neil J. Smelser's Value-Added Collective Behaviour scheme to describe the determinants of their collective action against the European Union. The result of this research is that Euroscepticism spreads throughout Europe by manifesting their critical ideas through six determinants factor, such as structural conduciveness, structural tension, growth, and spread of general beliefs, trigger factors, participant mobility, and social control. The manifestation of critical ideas carried out by Euroscepticism parties in the three countries can be seen through the Single European Act, Maastricht Treaty, Treaty Establishing Constitution for Europe, Referendum British Exit. The culmination of collective action by the Eurosceptic parties was the launch of EU critical campaigns (No to EU!) As well as a significant vote in the EU parliamentary elections. 


\section{Keywords: Collective Behaviour, Criticism, Euroscepticism, Value-Added Scheme}

\section{INTRODUCTION}

This research discusses the collective manifestation of the Eurosceptic party's critical ideas in the European Union Treaties. In general, some events that became the dynamics of the EU were the rejection of the Maastricht Treaty in Denmark, the Lisbon Treaty in Ireland in 2008 (BBC News, 2008) and the rejection of the EU Constitutional agreement in 2005 by the Netherlands and French (The Guardian, 2005). EU has attempted to build political space on the constitution and democratization through the Lisbon Treaty. This treaty amended the European Union Treaty and the treaty establishing the European Community (European Parliament, 2019). A Long history has colored the political conditions of the EU, both before and after the EU has formed.

Europe Integration works from the European Coal and Steel Community (ECSC) to the formation of the union signed by 26 European Economic Community (EEC) countries, becoming European Union (European Union, 2014). Unfortunately, for more than two decades since the birth of the term Euroscepticism, the EU has been flooded with skeptical criticism in doubting the benefits of joining the EU or ratify EU agreements. Euroscepticism has practically manifested by movements and political entities that oppose EU policy (Ozlem Ultan \& Ornek, 2015). The term Euroscepticism first appeared in the British media 'The Times' in November 1985, containing criticism towards the idea of integration. The term Euroscepticism reflects British elites' attitudes and reactions, either having doubt principal or in an opportunist view. The reflection of the British elite's attitude was conveyed officially by Prime Minister Margaret Thatcher's' Bruges Speech' in September 1988. The speech's containing internal political criticism in the UK, which later became a skeptical view if Britain should be involved in the idea of European Union Integration (Foster, 2002).

To see how this skeptical view has taken place in the course of the EU journey, starting from the Maastricht Treaty. European Union integration shows rapid development, and more countries are joining. This integration regulates the continued development of cooperation. On February 7,1992, the Treaty on European Union (TEU) was signed in Maastricht, signaling the EC's change to European Union, and entered into force on November 1, 1993 (Usherwood, 2014). When the Maastricht Treaty began, it was a sign of national borders' fading in member countries' domestic policies, especially in the political, economic, social, legal, environmental, and foreign affairs fields. The situation became the vortex of criticism towards EU integration in the future. Countries begin to think about the profit and loss ratio when ratifying a policy issued by the EU. Maastricht Treaty has provided a gap for Eurosceptic actors to spread their wings to show their critical thoughts toward the EU (Szczerbiak \& Taggart, 2008). The Eurosceptic party's issue strengthened during the European Union parliamentary elections on 22-25 May 2014; the result was quite surprising. Eurosceptic party vote soared up to one-third of the European Parliament seats. 
The Eurosceptic party's issue strengthened during the European Union parliamentary elections on 22-25 May 2014; the result was quite surprising. Eurosceptic party vote soared up to one-third of the European Parliament seats (BBC News, 2014a). In the 2014 Parliamentary Elections, the National Front Party won $24.86 \%$ of the votes and was entitled to get 23 seats in the European Union Parliament (Vandoorne, n.d.). In the 2009 parliamentary elections, the National Front gained $6.34 \%$ or only gained three parliamentary seats (European Election Database, n.d.). Meanwhile, the United Kingdom Independence Party in the 2014 European Union Parliamentary Elections received 27.49\% with 24 seats (BBC News, 2014b). In 2009, the United Kingdom Independence Party only gained $16.5 \%$ or 13 seats (BBC News, 2009).

This research will describe the history of the emergence of Euroscepticism and its roles in the European Union treaties from time to time. The authors try to explain the widespread dynamic in the Maastricht Treaty, Treaty Establishing Constitution for Europe, and the Lisbon Treaty. The discussion will focus on the Eurosceptic Parties of several EU countries. This selection of parties is needed to elucidate each party's development to its position based on the classification of Hard or Soft Euroscepticism and their involvement in criticizing EU treaties. The manifestations lead to the acquisition of each party's vote in European parliamentary elections. Those parties are Freiheitlische Partei Österreich (FPO), Austria; Front National (FN), France; Lega Nord (LN), Italy; Partij Voor de Vrijheid (PVV), Netherlands; and United Kingdom Independence Party (UKIP), UK. The undeniable facts and dynamics that occur at the EU have made the spread of Euroscepticism wider. British exit is not the only phenomenon that raises questions for the integrity of the EU.

Several other countries such as Austria, France, and Italy have demonstrated more substantial growth of Euroscepticism. In this research, the author is questioning how the collective manifestation of the Eurosceptic Party and Eurosceptic Movement in European Union treaties.

\section{THEORETICAL FRAMEWORK}

\section{Euroscepticism}

The basic idea of Euroscepticism was initially a rooted question about the future of EU integration. At first, Euroscepticism was a term to describe negative attitudes towards European integration. The conceptualization and definition of Euroscepticism have certainly been widely discussed by previous researchers and then raises many questions and problems in each of its researches. The researchers also agreed that the emergence of this terminology originated from the world of journalism in the UK, which is then embedded in history and has very diverse interpretations. (Effing et al., 2011) This question became so exciting yet so risky and also debatable through all the process of the integration. Again, the question seemed to be the beginning of a turning point in EU integration. These skeptical thoughts and actions 
eventually spread to many member countries. The birth of Euroscepticism parties has increased the dynamics of the EU integration process from a different perspective. The dynamics are so attractive when the Euroscepticism process of growth and development coincides with the increasing number of other European countries who wish to join the European Union and undergo the entire process of becoming a member of the European Union. Euroscepticism arises due to several domain factors found in Europe related to the mistrust of the EU (Munzilin, 2016).

To understand the doubts that arise, this is due to problems related to the economy where the crisis in Europe caused economic instability in almost all countries in Europe, especially countries that are part of EU membership. Second, the issue of sovereignty has been intervened by the EU towards its member countries. This condition makes the autonomy of the state not wholly perfect. The sense of nationalism is getting stronger because of the fear taken over their sovereignty by the EU. Third, related to democratization in Europe, the EU seems no longer able to manage and accommodate democratic participation from the community in making a policy (Hooghe \& Marks, 2007).

The question that should arise in understanding Euroscepticism is when a group or party is considered skeptical and the appropriate indicators to confirm that the parties and groups belong to Eurosceptic forms. Paul Taggart analyses there are three indicators to see whether these parties and groups belong to Euroscepticism. The first indicator is a sense of the decline of the permissive consensus and difficulties ratifying treaties. The second indicator is the existence of stimulation concerned with EU level issues which are precisely motivated by the EU integration project itself. Furthermore, the third indicator is the criticism of the expansion of the European Union, which has increasingly enlarged the scope of integration projects in various fields (Taggart, 1998). This concept is to justify the existence of parties that are contrary to EU policy. Euroscepticism is still a puzzle that has not ended yet for the European Union. Nevertheless, the skeptical thoughts and doubts about EU integration increasingly eager to encourage their countries to conduct a referendum that would determine whether the country would remain a member of the EU or leave the EU as Britain had done in the Brexit referendum last 2016.

\section{Collective behaviour}

Collective behavior defines as any event where a group of people engages in unusual behavior. An unexpected event is not commonly done during normal circumstances and is not normally done to people in general. Collective behavior is a bit contrary to normal human behavior and social expectations of the community. Collective behavior is characterized by spontaneity and weak internal structure. As with any social phenomenon, it is defining collective behavior refers to social processes and events that do not reflect existing social structures like laws, conventions, or institutions. This collective behavior arises spontaneously. 
Collective behavior is an action that results from something that is not following applicable or deviant norms (Ginneken, 2003).

The framework of theory used in this paper is collective behavior by Neil J. Smelser. Smelser explained that collective behavior is a community's activity in a crowd through direct contact between individuals who are members of a particular temporary or permanent group. Trust-based collective behavior is the basis of social action, a group of individuals who react to a particular situation. Social action is an action taken by many people with the same goals and interests. In his book, Smelser explains in detail that there are six determinants of the emergence of collective behavior. The six determinants are structural conduciveness, structural strains, growth and spread of generalized beliefs, mobilization of participants for actions, and the operation of social control (Smelser, 1962).

The first determinant is social conduciveness within a community or group's structural condition that can potentially form collective behavior. Individuals' plurality that raised a competition between certain groups and ended with the community's social instability motivated the social conduciveness. The second determinant is the structural strain. In explaining collective behavior, structural considerations are essential in the scope of social conduciveness. Otherwise, this tension will increasingly cause panic. The panic that occurs in society is a combination of social conditions that are not conducive and the high tension. This structural strain also resulted from disparities and discrepancies between social groups, including ethnicity, religion, the economy of people who live in the same scope and are close together. The third determinant is the growth and spread of a generalized belief. Smelser said that some types of strains could cause assumptions that are circulating in the community. The reason for the occurrence of collective behavior is not only due to structural tensions but also a belief in society. This process involves the growth and distribution of shared beliefs about the conditions and the surrounding situation that are unsatisfactory that require change. The fourth determinant is Precipitating factors. Precipitating factors support suspicion and anxiety, which delivers rumors. Next, the rumors circulating and trusted by the community then become an idea. The fifth determinant is the mobilization of participants for action. Participants' mobilization is the first step of collective behavior that there is a vital role of the group's leaders. Finally, the last or sixth determinant is an operation of social control. This social control mechanism can be in the form of a police, government, or media institution, which continuously prevents the accumulation of the five previous factors (McDaniel, 1971). The authors also need collective behavior to accommodate the Eurosceptic parties' critical ideas in the EU project based on the six determinants above.

\section{RESEARCH METHOD}


The type of method used in this research is the descriptive method. The approach used in this study is qualitative. Descriptive research is a research method to describe the current phenomenon, which took place at present or in the past. Descriptive research tends to describe a phenomenon as it is by examining it in a strict-regular manner, prioritizing objectivity and carried out in detail and systematically (Sukmadinata, 2008).

The data analysis technique used in this research is the inductive method. The inductive method is understood as an analytical approach to find research results with a specific-to-general way of thinking. The use of inductive methods encourages the completion of particular case studies through a theory. The theory used in this thesis aims to help the writer describe the data to be analyzed (Kasiram, 2010).

A method of data collecting technique used in this study is a literature study. The author gets the data through books, journals, online media, printed media, essays, thesis, and scientific papers. These data are analyzed with the concepts used in this study to see whether they correlate with the research's contents described by the author. To organize this paper into an appropriate timeline, the author sets the time limit of the discussion about the widespread of Eurosceptic party and Movement between 1985 2019. The author chose 1985 as a starting point of the Euroscepticism phenomenon in the EU based on all the literature review that discussed Euroscepticism terminology's appearance.

\section{RESULT AND DISCUSSION}

\section{The Manifestation of Eurosceptic Parties and Groups Critical Ideas in EU Treaties}

As the authors mentioned in the introduction, this research explains some highlighted phenomenon, in this case, the primary EU agenda to describe Euroscepticism's involvement in EU treaties. If we trace, this Euroscepticism term was first contained in a journalistic article written in November 1985 to express the tendency of 'skeptic-euro' alternately with 'anti-marketeer.' This tension finally resulted in British extremism's connotation over hostility and rejection of British participation in EU membership (Vasilopoulou, 2010). Although the roots of Euroscepticism history come from the United Kingdom, this terminology is increasingly developing in other EU countries, especially since the Maastricht treaty ratification in 1992 (Mudde, 2007).

\section{Maastricht Treaty}

The Maastricht Treaty introduces a new EU system works based on three pillars. The first pillar is European Communities, which have the qualifications in decision-making based on a system where most of the members come to a state, follow some rules, and decide on the procedures to be carried out. In general, this means the loss of national sovereignty because one-member states can be 'defeated' by 
other members and forced to adopt any rules designed by the EU. This idea seems better if done by sharing sovereignty rather than losing it (Moravcsik, 1995).

The second pillar is an intergovernmental organization for the Common Foreign and Security Policy. The member's countries consider this pillar is a way of developing policies in the union. This pillar also allows the development of policy under the umbrella of the European Union. The agreement to integrate the various positions of member countries, including in coordinating external policies of member countries. This effort is to realize a substantial agreement and avoid losing the member countries' sovereignty in specific policies that are sensitive (Kerikmäe \& Chochia, 2016).

The third pillar is a unified structure based on cooperation on justice and domestic affairs, especially asylum, cross border issues, customs, drugs, and immigration policy. This problem arises from the single European act and Schengen due to the widespread movement of people and goods in public areas. Therefore, this pillar is intended to control the same problem and has been chosen to prevent adverse effects. However, there is a more serious problem related to this pillar; member countries cannot take essential steps in this integration. It is quite similar to creating a European version of the United States (Kubosova, 2005).

Based on the three pillars and each problem that arises, the Maastricht agreement is considered a turning point of upheaval carried out by member countries. Denmark is a member country that refuses to ratify the Maastricht agreement of $50.7 \%$ and $49.3 \%$ (Cullen, 2001). The Danish people's failure to ratify the Maastricht treaty is an early signal of an increase in the reluctance of member states in the future to implement policies that are important for the progress of the European Union. Denmark's rejection of the Maastricht agreement indicates a possible gap in the future that the European Commission can be forced to function without its member states (Bierman et al., 1992).

\section{Treaty Establishing a Constitution for Europe (TCE)}

TCE was an agreement that sets a constitution for Europe, which was adopted by the European Council on June 18, 2004. It was signed in Rome at the end of the year with the President of the European Parliament, Josep Borell Fontelles. In short, this agreement contains proposals for official recognition of the European Union flag, anthem, and the motto of the European Union even though it has been there before and there is no change. TCE includes conferral, subsidiarity, and proportionality. TCE covers three things about the function of the European Union:

1. The conferring function contains that member countries voluntarily give all EU competencies.

2. Government decisions must be taken at the lowest possible level but must continue to run effectively. 
3. The principle of proportionality that the EU can only act to the extent necessary to achieve integration.

Besides, EU Law has priority in areas where member countries that have ratified agreements binding on legal equivalents at the EU level are not permitted to pass national laws that are not according to EU law (European Union, 2005).

The European Parliament approved this agreement. Unfortunately, in ratification, TCE was rejected by France on May 29, 2005 (BBC News, 2005b) and the Netherlands on June 1, 2005 (Simons, 2005) in their national referendum. The result of this agreement had not ratified by most EU member states (European Parliament, n.d.-a). This rejection by France and the Netherlands had strong prominent actors for providing skepticism towards the European Union. The three principles put forward in the TCE triggered the rejection of ratification by the two countries. In France, the result for the vote was $55 \%$ against and $45 \%$ in favor. The rejection in France was motivated by the entire domestic political spectrum, including the communist parties and right-wing parties. One of them was Philippe de Villiers, leader of Mouvement pour la France, a far-right Eurosceptic party that urged President Chirac to withdraw from TCE (BBC News, 2005b).

The rejection of TCE was not only carried out by France but also the Netherlands. An opinion poll was released immediately after the vote's close and showed $61.6 \%$ of voters in the Netherlands rejected the agreement. Prime Minister Jan Peter Balkenende expressed his dissatisfaction with the results but still respectfully accept them. This response is inversely proportional to Geert Wilders. The former leader of the right-wing Eurosceptic party Partij Voor de Vrijheid (PVV), had expressed some satisfaction towards the TCE results in the referendum vote (BBC News, 2005a). This rejection was partly motivated by the influx of around 700,000 Muslims from North Africa and other countries to the Netherlands. Specifically, that is the concern of the radicalization of Muslim youth across Europe. Fears of Islamic extremism mounted, leaving the Netherlands worried about a more lenient EU control over immigration and asylum policies (Beehner, 2005). These rejections and cancelations led to the non-ratification of the TCE agreement.

As of the data above, the outbreak of delays and rejections in the EU constitution's ratification resulted in the TCE's non-ratification as the official constitution. France and Netherlands ' far-reaching rejection with some Eurosceptic parties behind it became a magnet for eight other member countries to finally 'join in' delaying. Those countries are the Czech Republic, Denmark, Finland, Ireland, Poland, Portugal, Sweden, and the United Kingdom. Until finally, four years later, the EU showed up with the Lisbon Treaty.

\section{Lisbon Treaty}

On December 13, 2007, the Treaty was signed and entered into force on January 1, 2009. The Lisbon Treaty differs specifically from the TCE because the Lisbon Treaty does not contain articles formally governing Union law's supremacy over national laws. It is not surprising why many member states disagree 
with this point in the TCE. Lisbon treaty can be more lenient because it clarifies union power that distinguishes three types of competencies. Among these competencies are exclusive competence, shared competence, and supporting competence (European Parliament, 2019).

The Lisbon treaty and Euroscepticism link were robust when Ireland rejected signing the Treaty on June 12,2008 . The rejection was motivated because the Lisbon treaty's Irish vote took place amid substantial Irish internal political changes. Ireland continues to feel that the European Union's development is not in line with the domestic political agenda. Moreover, Taoiseach still dominates Ireland very much; again, the Lisbon Treaty does not appear to be responded attractively by the government and local communities, even into the campaign's final weeks. Instead, civil society groups began a campaign for the government to reject the Treaty. Libertas, a civil society group that is intensively carrying out posters containing the points why Ireland should reject the Lisbon Treaty. The leader launched the 'NO to Lisbon Treaty' campaign through influential media in Ireland (McGee, 2009). Besides Libertas, Catholic Cóir (Millar, 2009) and the People's Movement (People's Movement, n.d.) in February 2008 also collected the mass to spread leaflets on the Lisbon rejection Treaty campaign. On the other hand, the 'Yes to the Lisbon Treaty' campaign by the Alliance for Europe was formed at the end of April 2008 (Fitzgibbon, 2009).

Table 1: Eurosceptics Parties or Groups behind the Rejection of EU Treaties

\begin{tabular}{|c|c|c|}
\hline EU Treaties & $\begin{array}{l}\text { Party/Group/ } \\
\text { Individual }\end{array}$ & Role during Referendums \\
\hline $\begin{array}{l}\text { Maastricht } \\
\text { Treaty/Treaty } \\
\text { European } \\
\text { (1992) }\end{array}$ & $\begin{array}{l}\text { The European Alliance } \\
\text { of } \quad \text { EU-Critical } \\
\text { Movement (TEAM) }\end{array}$ & $\begin{array}{l}\text { Establishing a group opposing } \\
\text { Maastricht Treaty and held a } \\
\text { counter-summit in Edinburgh with } \\
\text { the base rejection of single euro } \\
\text { currency. (TEAM, n.d.) }\end{array}$ \\
\hline \multirow[t]{2}{*}{$\begin{array}{l}\text { Treaty Establishing a } \\
\text { Constitution for } \\
\text { Europe (2005) }\end{array}$} & $\begin{array}{l}\text { Philippe de Villiers } \\
\text { Leader of } \\
\text { Mouvement pour la } \\
\text { France }\end{array}$ & $\begin{array}{l}\text { Insist President Chirac to withdraw } \\
\text { from TCE. (CNN, 2005) }\end{array}$ \\
\hline & $\begin{array}{l}\text { Geert Wilders } \\
\text { Leader of Partij voor de } \\
\text { Vrijheid (PVV) }\end{array}$ & $\begin{array}{l}\text { Initiate the Dutch campaign to reject } \\
\text { European Constitutions. Showing off } \\
\text { satisfaction towards the higher 'No' } \\
\text { vote in Netherland. (Spoerri, 2013) }\end{array}$ \\
\hline \multirow[t]{3}{*}{ Lisbon Treaty (2009) } & Libertas & \multirow{3}{*}{$\begin{array}{l}\text { Launched a 'No to Lisbon' campaign } \\
\text { and spreading leaflets to get bigger } \\
\text { mass on opposing Lisbon. } \\
\text { (Fitzgibbon, 2009) }\end{array}$} \\
\hline & Catholic Cóir & \\
\hline & People's Movement & \\
\hline
\end{tabular}

\section{Types of Euroscepticism}


Euroscepticism expresses the idea of opposition to EU integration. The manifestations of the opposition's idea movement in EU member states need classification. This classification will be useful to see how the spread of skeptical ideas can occur. This sub-chapter will elaborate specifically on Euroscepticism types based on the three major EU treaties explained in the previous sub-chapter. Taggart divides Euroscepticism into two, namely Hard Euroscepticism and Soft Euroscepticism (Taggart \& Szczerbiak, 2001).

Hard Euroscepticism and Soft Euroscepticism oppose the integration process at different levels, and their differences closely reflect the pattern of public opinion towards the EU. Hard Eurosceptic rejected the EU project because they strongly opposed making European policy and the rules and procedures that apply at the EU level. While Soft Euroscepticism focuses more on their skeptical views on some specific policies, or procedural aspects of the EU, it does not reject the EU as a whole. (Vries, 2018).

Table 2: Defining Hard and Soft Euroscepticism \& their Behaviour Towards European Union

\begin{tabular}{|l|l|l|}
\hline & Hard Euroscepticism & Soft Euroscepticism \\
\cline { 2 - 4 } Main Principal & $\begin{array}{l}\text { Principal rejection of the } \\
\text { European integration project } \\
\text { and all regulations made by } \\
\text { the EU. (Szczerbiak \& Taggart, } \\
\text { 2003) }\end{array}$ & $\begin{array}{l}\text { It has no major objections in } \\
\text { the European integration } \\
\text { project in the transfer of power } \\
\text { to the EU supranational body, } \\
\text { but is contradictory to current } \\
\text { EU specific policies, or future } \\
\text { planned EU trajectories. } \\
\text { (Verney, 2011) }\end{array}$ \\
\hline $\begin{array}{l}\text { Party or Group-based } \\
\text { overview }\end{array}$ & $\begin{array}{l}\text { Hard Euroscepticism parties } \\
\text { mainly have the biggest goal } \\
\text { that their country must } \\
\text { withdraw from EU accession. } \\
\text { (Szczerbiak \& Taggart, 2003) }\end{array}$ & $\begin{array}{l}\text { The soft Euroscepticism party } \\
\text { considers that the EU treaty is } \\
\text { a highly calculated moment } \\
\text { related to the direction of EU } \\
\text { integration. So, the political } \\
\text { statement made by abstaining } \\
\text { or voting against it.(Verney, } \\
2011)\end{array}$ \\
\hline Main Issue & $\begin{array}{l}\text { EU Power, Unemployment, } \\
\text { and Immigration. }\end{array}$ & $\begin{array}{l}\text { National Sovereignty, Euro } \\
\text { Single Currency. }\end{array}$ \\
\hline
\end{tabular}

Hard Euroscepticism implies the direct rejection of all EU political and economic integration projects. Theoretically, this type of Euroscepticism tends to be hard in expressing principal objections to any EU ideas. Meanwhile, practically Hard Euroscepticism can be identified with the firm principle that the EU opposes and obstructs a particular party's values or movement. Generally, this kind of party plays a dominant issue as its main criticism of EU integration, such as EU power, immigration, and unemployment (Brack \& Startin, 2015). The Hard Euroscepticism parties they have mentioned are Freiheitliche Partei 
Österreichs (FPÖ) and the United Kingdom Independence Party (UKIP), United Kingdom (Sara B. Hobolt \& de Vries, 2016).

Soft Euroscepticism is a reformist type that supports the existence of the European Union and its members. However, it is critical of specific policies regarding EU integration and the idea of a federal Europe. Soft Eurosceptic parties prioritize national sovereignty issues among member states (Ozlem Ultan \& Ornek, 2015). However, this type of soft Euroscepticism is considered more problematic because the opposing idea lies in concern of policy areas that lead to the expression of a country's national interests that are odds with the EU trajectory (Taggart \& Szczerbiak, 2002). Nevertheless, this term persists and emphasizes the binary terminology between 'hard' and 'soft', which makes this study interesting. Soft Euroscepticism exists to enable us to grasp the concept of a stand-alone space between those who oppose the EU as a whole and those who glorify European integration (pro-EU). Those parties are Partij Voor de Vrijheid (PVV), Austria; British Conservative Party, United Kingdom; and Democratic Unionist Party, United Kingdom (Verney et al., 2013), (Sara B. Hobolt \& de Vries, 2016), (Ozlem Ultan \& Ornek, 2015).

In this chapter, the parties that have been discussed are the major parties that get a high vote in their national parliamentary elections so they can qualify for the European Parliament elections. These parties have gone through their Long journey in expressing their criticism of the EU. Not all parties are born 'Eurosceptic' due to some conditions and dynamics of EU integration, which eventually makes these parties turn around and start criticizing the EU. Austria is a country that is relatively young in EU membership since its entry in 1995. Austria is at a high level of interest in the EU, even the Yes to EU campaign supported by pro-European coalition parties has helped the success of Austria's accession. However, opposition opinion remains; in 1996, the Eurobarometer survey showed public opinion that as many as $27 \%$ of the public thought Austria's membership to the EU was 'a terrible thing'. That number is the same as people who think Austrian membership is a good thing. Austria itself experienced a shift in internal politics where after joining the EU, public expectations tended to be unfulfilled. Through this gap, Euroscepticism in Austria emerged and became the most vigorous opposition to the EU (Norks Senter For Forskningsdata, 1996, 1999a, 2004a, 2009a).

Meanwhile, France is one of the founding fathers who has faced the spread of Euroscepticism since the Single Euro Currency discourse to be implemented in the EU. The French political system with the two largest party streams has added to France's internal apolitical dynamics, including the EU opposition party. Ahead of the Maastricht Treaty, EU opposition was delivered by the National Front and Lutte Ouvriere in the 1990s. The National Front continues to grow as its skeptical ideas become more specific about antiimmigration. National Front topped the 2004 European Parliament Election with 24.84\% of votes. FN focuses on its central argument, which states that the EU has an oligarchic system with a totalitarian style. Speaking of Euroscepticism in Italy, it is almost impossible to detect Euroscepticism's spread because Italy 
can be categorized as a very supportive founding father country with all EU Agenda, including support for the Single Euro currency. Nevertheless, what is interesting is Lega Nord, the EU's strongest opposition party in Italy, intensifying anti-euro issues (Norks Senter For Forskningsdata, 1994, 1999b, 2004b, 2009b).

Euroscepticism does not always occupy a high position in every European parliamentary election. The Netherlands is a country with a widespread Euroscepticism that tends to be 'weak' in the last three parliamentary elections. The largest opposition party in the Netherlands is the PVV, which carries antiimmigration and anti-Islamism. At the same time, Euroscepticism in the UK is always a complex discussion. The hard-Eurosceptic opposition party in the EU, UKIP won an increasing vote every European Parliament election. Issues raised by the UKIP are the ideas' Leave EU' and 'No to Immigration' (Norks Senter For Forskningsdata, 2009c).

\section{The Manifestation of Eurosceptics Parties and Groups Critical Ideas based on Collective Behaviour Determinants}

In the theoretical framework, the authors have explained Collective Behaviour as a theory that will help the author answer the research questions. This section will discuss how the Euroscepticism phenomena in the European Union can meet the Collective Behaviour determinants that have been explained by Smelser. The author generally discusses Euroscepticism in Austria, France, the Netherlands, and the United Kingdom. The determinants include; Structural Conduciveness, Structural Strain, Growth, and Spread of a Generalised Belief, Precipitating Factors, Mobilisation of Participants, and the Operation of Social Control (Smelser, 1962).

This first determinant is critical to understand as a 'starting point,' and Euroscepticism requirements begin to be detected. The decision of time limits for this research starts in 1985. It is an appropriate consideration to analyze why Euroscepticism can spread and produce intense manifestations on each EU agenda. The expansion of the scope of cooperation at the EU level has slowly changed the EU's face in the eyes of its member countries. The transition of European Integration from ECSC to the European Community, which began to spread its wings through economic integration, is not considered an ordinary transition for some member countries. The birth of Euroscepticism terminology outside political discourse has more or less been a sign of a shift in EU perceptions for Britain delivered by Thatcher in a speech that emphasized criticism of economic integration, which will soon be carried out by the EU (Westlake, 2019).

The author sets the Single European Act as a fulfilling determinant of Structural Conduciveness. The idea of European Integration developed into the European Community was a clear signal of the beginning of skeptical ideas. The Single European Act offers the first significant reforms governing the expansion of the majority of votes that meet the European Council's requirements, increasing the 
European parliament's role in cooperative procedures, and most importantly, expanding the community. An outline of the Single European Act's objectives is the preparation of the internal market in 1992, the European Single Market (European Union, 2005).

The European Single Act led to the emergence of conditions where criticism of the EU project began. The European Union has expanded the Single European Act to launch euros for all EU countries. EU member countries respond to this with various reactions, most of which see the euro policy as the expropriation of each country's sovereignty to regulate its monetary policy. This tension occurs when some countries are unwilling to implement the Euro as a substitute for the national currency.

The author sets the Single Euro Currency policy as a structural strain determinant. More tension arises when Britain tries not to adopt the Euro as the official currency when it is still a European Union country. The British opted out of the creation of the Euro through the Maastricht agreement, 1992. The Bank of England is only a member of the European Central Bank system but is not part of the eurozone. This situation triggered the tension of other Eurosceptic parties who opposed the Euro, such as Lega Nord in Italy, even though nationally, Italy is a supportive country for euro policy. Lega Nord views that the Euro symbolizes the loss of state sovereignty to curb its monetary policy. Lega Nord insisted on the anti-euro issue and wanted to restore Lira as an Italian currency. The author has explained in the Eurosceptic subchapter based on the issue that this euro policy has more or less awakened Eurosceptic parties to fight back. The evidence from the UKIP encouraged EU member states to stop implementing the Euro. Furthermore, they restore 'national sovereignty' by re-using their national currencies (Huysseune, 2010).

The rejection and protest carried out by Eurosceptic parties over the Euro's implementation are considered only to make its member countries not having complete sovereignty, apparently making the Eurosceptic parties have a shared belief in the EU. The shared belief held by the Eurosceptic parties is that the $\mathrm{EU}$ is a body that regulates all supranational interests and contradicts the national interests of each member country. European institutions are seen as lacking transparency and accountability. This widespread and growing belief has resulted in a dramatic loss of trust in EU institutions. Tensions were arising from the EU integration process and the crisis of public confidence in EU institutions. These conditions further trigger the party and the Euroscepticism movement to find loopholes to articulate their dissatisfaction with the EU (Taylor, 2017).

The author sets the rejection of France and the Netherlands in TCE as a precipitating factors determinant. TCE is a referendum that is a 'fatal' in the failure of ratification by EU members. The fact that the two European founding countries rejected the referendum triggered other countries to cancel the TCE ratification. This rejection was motivated by the dominant issues in the two countries. France is more focused on economic and social issues, while the Netherlands focuses more on cultural and identity issues. The two countries' skeptical values are different because the French people are more skeptical about the 
liberal market economy and the loss of the French social model. In contrast, the Dutch people tend to worry about losing their national cultural identity (Sara Binzer Hobolt \& Brouard, 2011).

The campaigns carried out by the Euroscepticism parties on the issues that were the focus of their criticism of the EU were the most apparent manifestations of the idea of opposing the EU. The ideas echoed by the Euroscepticism party more or less affect the internal political direction, even more so if they have occupied the European parliament's seat with a significant amount. The author sets the British Exit campaign as a determinant Mobilization of Participants. Nigel Farage was one of the most influential Eurosceptic individuals in the Brexit era. Farage describes Britain's importance in withdrawing from EU membership solely based on 'taking back the full control' to the United Kingdom. Identifying the nation-state with national interests has always been crucial in building and public confidence in the government. Public and Elite awareness in the UK takes enormous political, economic risks to protect what they perceive as national interests and vital identity (Vries, 2018). Brexit is not the only massive campaign carried out by the Eurosceptic party and the development of European integration. The discourse of membership withdrawal by France, the Netherland, Austria also began to appear even though the issue is still considered a nationalist issue that is still far from the referendum manifestation. However, at least the discourse has emerged and is prepared to widen sometime. French exit or Frexit, Netherland exit or Next, and Austria exit or Auxit may become a movement in the years to come after the Brexit referendum.

The massive development of Euroscepticism in Europe has become a heavy burden for EU officials to maintain integration. It remains intact as the most extensive integration in the world. Social control is needed as a determinant measure so that the chaos created by Euroscepticism does not have a negative impact in the short term for the EU. The author sets the European Parliament a social control determinant. European Parliament currently consists of several political parties in which there is a combination of national political parties with different ideologies. Two EP parties have Euroscepticism, Identity and Democracy Group, and European Conservatives and Reformist Group. Their presence amid the pro-EU party is proof that social control continues to run despite the healthy development of Euroscepticism in the European Parliament (European Parliament, n.d.-b).

Figure 1: Summary of Collective Behaviour Determinant Analysis: Research Result Scheme 


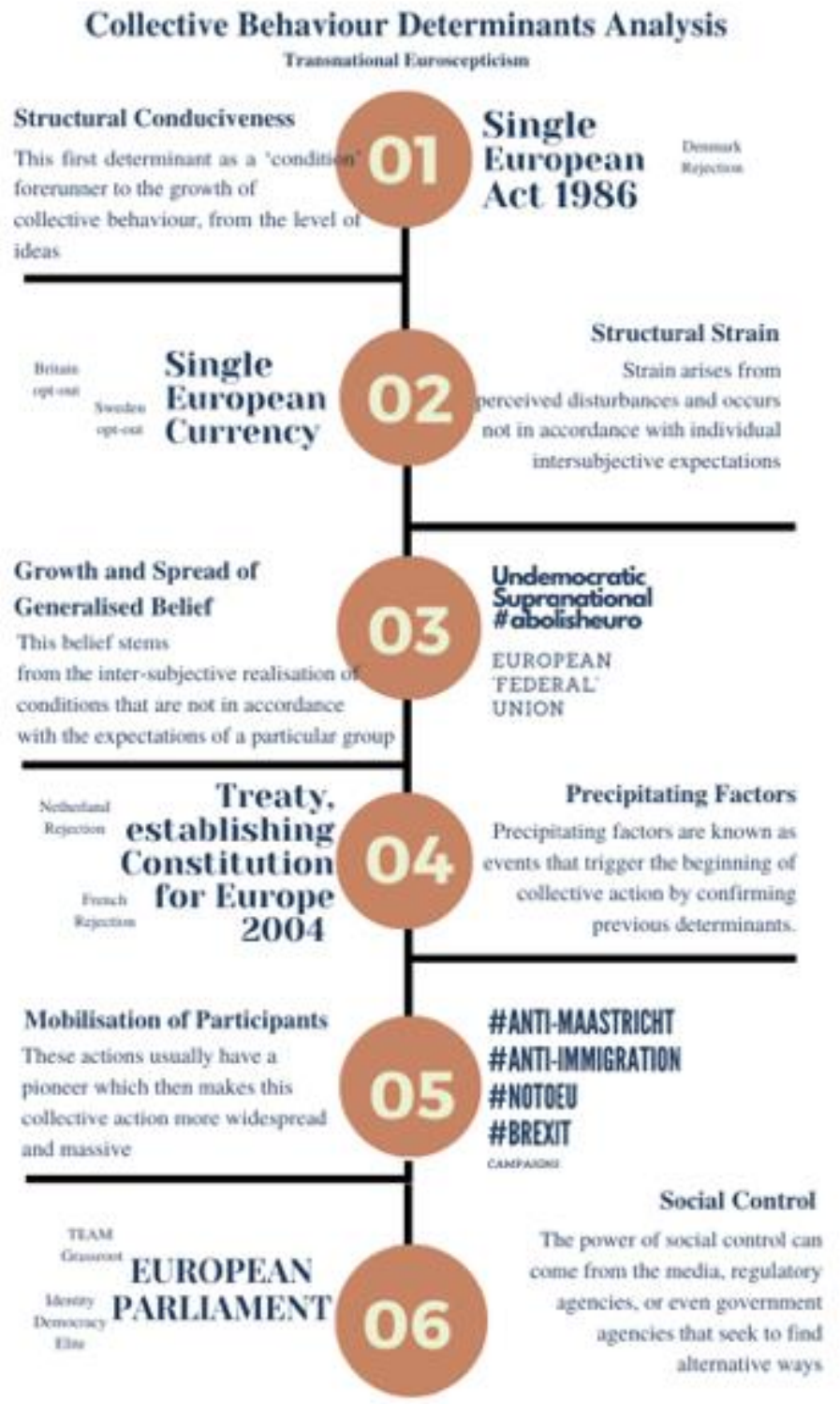

Those determinants have shown that Euroscepticism spreads and developing along with the EU agenda. Euroscepticism adheres to one main criticism: the expansion of integration, deprivation of democracy, and the fading sovereignty of each EU member state. In order to answer the research question in the first chapter, Euroscepticism spread gradually through six determinants. The Single European Act became the first determinant because the SEA marked the European transition from economic cooperation to political union, which caused Denmark to delay ratification. After all, it did not follow Danish values and identity. Then, the Single European Currency becomes the structural strain determinant. Lega Nord and UKIP are disappointed by the EU over the euro policy widespread Eurosceptics Parties and Groups based on Collective Behaviour Determinants. 'No to EU' become the third determinant of the growth and spread of generalized belief. The shared belief held by the Eurosceptic parties is that the EU is a body that regulates all supranational interests and contradicts the national interests of each member country. The fourth determinant is the Precipitating factors, the fact that the two European founding 
countries rejected the referendum triggered other countries to cancel the TCE ratification. The fifth determinant is the Mobilisation of Participants. The campaigns carried out by the Euroscepticism parties on the issues that were the focus of their criticism of the EU were the most apparent manifestations of the idea of opposing the EU. Moreover, the last, the European Parliament, is the social control determinant.

To conclude this chapter from the country's perspective, Austria is a country with a high degree of growth Euroscepticism; this can be seen from the results of the European Union parliamentary elections, which the author has explained. Based on the theory of collective behavior in the distribution of Euroscepticism parties in each EU agreement, there is a culmination point or the culmination of these phenomena, making this distribution more massive. The whole phenomenon that became the authors' discussion between 1985 and 2019 was the accumulation of manifestations of criticism carried out by the parties and Euroscepticism groups towards the European Union. Among these phenomena, France and the Netherlands' rejection of the Treaty Establishing Constitution for Europe (TCE) was the biggest trigger. In short, TCE regulates the provisions regarding transfer-value from EU member states. The rejection has triggered member states' refusal because the three pillars proposed in the TCE can diminish each member country's national sovereignty. TCE was finally not ratified by eight other member countries including the Czech Republic, Denmark, Finland, Ireland, Poland, Portugal, Sweden, and the United Kingdom.

\section{CONCLUSION}

Euroscepticism spread gradually through six determinants. The Single European Act became the first determinant because the SEA marked the European transition from economic cooperation to the political union, which caused Denmark to delay ratification. After all, it was not following Danish values and identity. Then, the Single European Currency becomes the structural strain determinant. Lega Nord and UKIP are disappointed by the EU over the euro policy the widespread of Eurosceptics Parties and Groups based on Collective Behaviour Determinants. No to EU' become the third determinant of the growth and spread of generalized belief. The fourth determinant is the Precipitating factors, the fact that the two European founding countries rejected the referendum triggered other countries to cancel the TCE ratification. The fifth determinant is the Mobilisation of Participants. The campaigns carried out by the Euroscepticism parties on the issues focused on their criticism of the EU as the manifestation of criticism ideas. Furthermore, the last, the European Parliament, is the social control determinant. The presence of Eurosceptic Parties during the pro-EU party is proof that social control continues to run despite the healthy development of Euroscepticism.

Exploring Euroscepticism does not mean merely looking for causes and consequences of the EU opposition movement. However, more than that, Euroscepticism can be understood as the political dynamics that characterize European integration's intricacies. Based on this research's conclusion, the 
author argues that Euroscepticism must be commensurate with studying EU integration itself. Although Euroscepticism's terminology was not born from political discourse, this critical idea has been there to give the $\mathrm{EU}$ an evaluation and critique of specific policies. The most important thing to always remember is, Euroscepticism is not merely a matter of Brexit and vice versa.

\section{BIBLIOGRAPHY}

BBC News. (2005a). Dutch Say No to EU Constitution. One-Minute World News.

BBC News. (2005b). French Say Firm "No" to EU Treaty. One-Minute World News.

BBC News. (2008). Ireland Rejects EU Reform Treaty. BBC News.

BBC News. (2009). European Election 2009: UK Results.

BBC News. (2014a). Eurosceptic "Earthquake" Rocks EU Elections. BBC News.

BBC News. (2014b). UK European Election Results.

Beehner, L. (2005). European Union: The French and Dutch Referendums. Council on Foreign Relations. Bierman, L., Kolari, J., \& Pustay, M. W. (1992). Denmark and Maastricht Treaty: A Market Analysis. Duke Journal of Comparative \& International Law, 3, 147.

Brack, N., \& Startin, N. (2015). Introduction: Euroscepticism, from the margins to the mainstream. International Political Science Review, 36(3), 239-249. https://doi.org/10.1177/0192512115577231

CNN. (2005). France Set for Government Shake Up.

Cullen, P. (2001). Denmark rejected EU on two occasions. The Irish Times.

Effing, R., van Hillegersberg, J., \& Huibers, T. (2011). Social Media and Political Participation: Are Facebook, Twitter and YouTube Democratizing Our Political Systems? In E. Tambouris, A. Macintosh, \& H. de Bruijn (Eds.), Electronic Participation (pp. 25-35). Springer Berlin Heidelberg.

European Election Database. (n.d.). French Dataset: European Parliamentry Election 2009.

European Parliament. (n.d.-a). Draft Treaty Establishing a Constitution for Europe (Not Ratified). About Parliament.

European Parliament. (n.d.-b). The Political groups of the European Parliament. European Parliament. (2019). The Treaty Of Lisbon. European Union FactSheet.

European Union. (2005). Treaty Establishing a Constitution for Europe. In Official Journal of the Europan Union. Official Pulications of the European Communities.

European Union. (2014). The European Union explained: How the EU works. Publications Office of The European Union. https://doi.org/10.2775/11255

Fitzgibbon, J. (2009). Why did Ireland Reject the Lisbon Treaty in 2008? Faith in Europe.

Foster, A. (2002). Euroscepticism in contemporary British politics: opposition to Europe in the British Conservative and Labour Parties since 1945. Routledge. 
Ginneken, J. Van. (2003). Collective Behavior and Public Opinion: Rapid Shifts in Opinion and Communication. In The European Institute for the Media. Lawrence Erlbaum Associates Publisher. Hobolt, Sara B., \& de Vries, C. (2016). Turning against the Union? The impact of the crisis on the Eurosceptic vote in the 2014 European Parliament elections. Electoral Studies, 44(June 2016), 504514. https://doi.org/10.1016/j.electstud.2016.05.006

Hobolt, Sara Binzer, \& Brouard, S. (2011). Contesting the European Union? Why the Dutch and the French Rejected the European Constitution. Political Research Quarterly, 64(2), 309-322. https://doi.org/10.1177/1065912909355713

Hooghe, L., \& Marks, G. (2007). Sources of euroscepticism. Acta Politica, 42(2-3), 119-127. https://doi.org/10.1057/palgrave.ap.5500192

Huysseune, M. (2010). A eurosceptic vision in a europhile country: The case of the Lega Nord. Modern Italy, 15(1), 63-75. https://doi.org/10.1080/13532940903477880

Kasiram, M. (2010). Refleksi Pengembangan Pemahaman dan Penguasaan Metodologi Penelitian (2nd ed.). UIN Maliki Press.

Kerikmäe, T., \& Chochia, A. (2016). Political and legal perspectives of the EU eastern partnership policy. In Political and Legal Perspectives of the EU Eastern Partnership Policy. https://doi.org/10.1007/978-3$319-27383-9$

Kubosova, L. (2005). Slovakia Freezes EU Constitution Ratification. EU Observer.

McDaniel, C. O. (1971). Structural conduciveness, structural strain, and the occurrence of race riots. South African Journal of Sociology, 1971(2), 3-22. https://doi.org/10.1080/02580144.1971.10433681

McGee, H. (2009). Libertas says it will play no role in Lisbon vote. The Irish Times.

Millar, S. (2009). Coir Anti Treaty Posters Trade for People's Fear. Irish Examiner.

Moravcsik, A. (1995). Liberal Intergovernmentalism and Integration: A Rejoinder. JCMS: Journal of Common Market Studies, 33(4), 611-628. https://doi.org/10.1111/j.1468-5965.1995.tb00554.x

Mudde, C. (2007). Populist Radical Right Parties in Europe. Cambridge University Press.

Munzilin. (2016). DINAMIKA PERKEMBANGAN EUROSCEPTIC DI UNI EROPA DAN REFERENDUM INGGRIS TAHUN 2016 [Universitas Muhammadiyah Yogyakarta]. https://doi.org/10.1017/CBO9781107415324.004

Norks Senter For Forskningsdata. (1994). European Electon Dataset France : European Parliament Election 1994.

Norks Senter For Forskningsdata. (1996). European Election Dataset Austria : European Parliament Election 1996.

Norks Senter For Forskningsdata. (1999a). European Election Dataset Austria : European Parliament Election 1999. 
Jurnal Studi Diplomasi dan Keamanan, Volume 13, No. 1, Januari 2021

Norks Senter For Forskningsdata. (1999b). European Election Dataset France: European Parliament Election 1999.

Norks Senter For Forsknings data. (2004a). European Election Dataset Austria: European Parliament Election 2004.

Norks Senter For Forskningsdata. (2004b). European Election Dataset France: European Parliament Election 2004.

Norks Senter For Forskningsdata. (2009a). European Election Dataset Austria: European Parliament Election 2009 Dataset.

Norks Senter For Forskningsdata. (2009b). European Election Dataset France: European Parliament Election 2009 (Vol. 2009).

Norks Senter For Forskningsdata. (2009c). European Election Dataset Netherlands: European Parliament Election 2009.

Ozlem Ultan, M., \& Ornek, S. (2015). Euroscepticism in the European Union. International Journal of Social Sciences, IV(2), 49-57. https://doi.org/10.20472/SS.2015.4.2.006

People's Movement. (n.d.). Referendum result is not an Endorsement of the Lisbon Treaty. Lisbon Treaty.

Simons, M. (2005). Dutch Voters Solidly Reject New European Constitution. The New York TImes.

Smelser, N. J. (1962). Theory of Collective Behavior. The Free Press. https://doi.org/10.2307/40176713

Spoerri, M. (2013). Netherlands: Geert Wilders, the Dutch "Cricket." International Institute for Political Studies.

Sukmadinata, N. S. (2008). Metode Penelitian Pendidikan. Remaja Rosdakarya.

Szczerbiak, A., \& Taggart, P. (2003). Theorising Party-Based Euroscepticism: Problems of Definition, Measurement and Causality. EPERN Working Paper, 69, 1-27.

Szczerbiak, A., \& Taggart, P. (2008). Opposing Europe: The Comparative Party Politics of Euroscepticism. Oxford University Press.

Taggart, P. (1998). A touchstone of dissent: Euroscepticism in contemporary Western European party systems. European Journal of Political Research, 33(3), 363.

https://doi.org/10.1023/A:1006853204101

Taggart, P., \& Szczerbiak, A. (2001). Parties, Positions and Europe: Euroscepticism in the EU Candidate States of Central and Eastern Europe (Issue 46).

Taggart, P., \& Szczerbiak, A. (2002). The Party Politics of Euroscepticism in EU Member and Candidate States. Opposing Europe Research Network Working Paper No 6, 51, 1-45.

Taylor, R. (2017). Euroscepticism has taken hold across the EU - but it has many different roots. LSE European Politics and Policy.

TEAM. (n.d.). Introduction to TEAM. 
The Guardian. (2005). Dutch Say "Devastating No" To EU. The Guardian.

Usherwood, S. (2014). Euroscepticism as a lever: Contesting European integration with ulterior motives. November, 1-16.

Vandoorne, S. (n.d.). France posts final results: Victory for Le Pen. CNN News.

Vasilopoulou, S. (2010). Euroscepticism and the Radical Right: domestic strategies and party system dynamics.

Verney, S. (2011). Euroscepticism in Southern Europe: A Diachronic Perspective. South European Society and Politics, 16(1), 1-29. https://doi.org/10.1080/13608746.2010.570124

Verney, S., Nanou, K., \& Clements, B. (2013). Soft Euroscepticism in The Spotlight: The Impact of The Economic Crisis in Greece. The 7th General Conference of the European Consortium for Political Research, Sciences, September, 1-31.

Vries, C. E. De. (2018). Euroscepticism is here to Stay. LSE European Politics and Policy.

Westlake, M. (2019). The more (European integration) there is, the more (Euroscepticism) there is: Euroscepticism as reactive identity formation and the impor- tance of opposition. Where might the EU institutions go from here? Bruges Political Research Papers, 73(66), 1-39. 